\title{
PENGARUH GAYA KEPEMIMPINAN, MOTIVASI KERJA, DAN LINGKUNGAN KERJA TERHADAP KINERJA KARYAWAN PT. ASURANSI JIWASRAYA DI BANDAR LAMPUNG
}

\author{
Rina Loliyana \\ Program Studi Manajemen, Fakultas Bisnis, Universitas Mitra Indonesia \\ * rinaloly123@gmail.com
}

\begin{abstract}
The purpose of this study was to determine whether leadership style, work motivation, and work environment affect the performance of employees in the PT. Asuransi Jiwasraya (Persero) Bandar Lampung. This study uses a quanitative method, with the number of samples in this study were 74 respondents. Data was analyzed using multiple linear regression. The results showed that leadership style (X1), work motivation (X2), and work environment (X3) simultaneously have a positive and significant effect on employee performance $(Y)$. Work motivation is the variable that has the greatest influence on employee performance in the PT. Asuransi Jiwasraya (Persero) Bandar Lampung.
\end{abstract}

Keywords: leadership styles, work motivation, work environment, employee performance

\begin{abstract}
ABSTRAK
Tujuan dari penelitian ini adalah untuk menentukan apakah gaya kepemimpinan, motivasi kerja, dan lingkungan kerja mempengaruhi kinerja karyawan di PT. Asuransi Jiwasraya (Persero) Bandar Lampung. Penelitian ini menggunakan metode kuantitatif, dengan jumlah sampel sebanyak 74 responden. Data dianalisis dengan menggunakan analisis regresi linier berganda. Hasil penelitian menunjukkan bahwa gaya kepemimpinan (X1), motivasi kerja (X2), dan lingkungan kerja (X3) memiliki pengaruh positif dan signifikan terhadap kinerja karyawan (Y). Motivasi kerja menjadi variabel yang memiliki pengaruh terbesar terhadap kinerja karyawan PT. Asuransi Jiwasraya (Persero) Bandar Lampung.
\end{abstract}

Kata kunci: gaya kepemimpinan, motivasi kerja, lingkungan kerja, kinerja karyawan

\section{PENDAHULUAN}

Perusahaan pada umumnya didirikan dengan tujuan dapat melangsungkan 
hidupnya untuk memperoleh keuntungan yang maksimal. Pengelolaan sumber daya manusia sangat penting dalam mencapai tujuan suatu permasalahan. Masalah sumber daya manusia saat ini masih tetap menjadi pusat perhatian bagi suatu perusahaan untuk bertahan di era globalisasi, perusahaan dituntut untuk melakukan persaingan usaha yang lebih kompetitif. Untuk menghadapi persaingan tersebut, setiap perusahaan harus memiliki sumber daya manusia yang kompeten untuk meningkatkan mutu dan kualitas dalam perusahaan untuk memajukan bisnisnya.

PT. Asuransi Jiwasraya (Persero) adalah Badan Usaha Milik Negara Indonesia yang bergerak di sektor asuransi. Menurut Kamus Besar Bahasa Indonesia (KBBI), asuransi adalah pertanggungan yaitu perjanjian antara dua pihak. Pihak yang satu berkewajiban membayar iuran dan pihak lain berkewajiban memberikan jaminan sepenuhnya pada pembayar iuran bila terjadi sesuatu yang menimpa pihak pertama atau barang miliknya sesuai perjanjian yang dibuat. PT. Asuransi Jiwasraya (Persero) memiliki beragam produk, baik individu maupun grup/kumpulan, dan selalu mengalami perkembangan dan peningkatan yang disesuaikan dengan kebutuhan dan kemampuan masyarakat untuk memberikan layanan prima bagi pemegang polis nya. PT. Asuransi Jiwasraya (Persero) di Bandar Lampung terletak di Jl. Raden Intan No.67, Enggal, Engal, Kota Bandar Lampung, Lampung.

Keberhasilan PT. Asuransi Jiwasraya (Persero) di Bandar Lampung dalam mencapai tujuannya tidak terlepas dari peran karyawannya, karena karyawan bukan semata sebagai objek dalam pencapaian tujuan organisasi, tetapi juga menjadi subjek atau pelaku. Mereka dapat menjadi perencana, pelaksana, dan pengendali yang selalu berperan aktif dalam mewujudkan tujuan organisasi, serta mempunyai pikiran, perasaan, dan keinginan yang dapat mempengaruhi kinerja, dedikasi, dan kecintaan terhadap pekerjaan yang menjadi tanggung jawabnya.

Walaupun asuransi Jiwasraya merupakan perusahaan BUMN yang besar di bidang asuransi, tetapi terdapat berbagai permasalahan yang terjadi di perusahaan tersebut, seperti pemimpin kurang memberikan motivasi kepada para karyawan, dan kurangnya komunikasi yang baik antara pemimpin dan karyawan, sehingga terjadi jadwal penagihan dan pembayaran asuransi yang tidak teratur. Karyawan juga memiliki motivasi rendah dalam bekerja. Hal ini disebabkan karena untuk mendapatkan insentif, karyawan harus bekerja mencapai target. Faktor lain yang menurunkan motivasi kerja karyawan adalah kurangnya penghargaan tunjangan prestasi kerja, dimana pembayarannya hanya berdasarkan faktor absensi saja, tanpa melihat output nyata karyawan, atau dengan kata lain karyawan yang memberikan kontribusi lebih dengan karyawan yang bekerja seadanya mendapat tunjangan prestasi kerja yang sama. Terdapat permasalahan juga berkaitan dengan lingkungan kerja, seperti tekanan dalam penyelesaian laporan yang sering diminta secara mendadak, dan harus selesai pada hari itu, membuat karyawan merasa kurang nyaman, dan terganggu kinerjanya. Faktor lain juga mengenai fasilitas kerja yang belum memadai hingga mengganggu kenyamanan. Berdasarkan permasalahan tersebut, tergambar bahwa terdapat beberapa faktor yang mempengaruhi kinerja karyawan PT. Asuransi Jiwasraya (Perseo), diantaranya seperti gaya kepemimpinan, motivasi kerja, dan lingkungan kerja.

Menurut Thoha (2014:303), gaya kepemimpinan merupakan norma perilaku yang 
digunakan oleh seseorang pada saat orang tersebut mencoba mempengaruhi perilaku orang lain seperti yang ia lihat. Sedangkan menurut Zainal, et al. (2014:42), gaya kepemimpinan adalah sekumpulan ciri yang digunakan pimpinan untuk memengaruhi bawahan agar sasaran organisasi tercapai, atau dapat pula dikatakan bahwa gaya kepemimpinan adalah pola perilaku dan strategi yang disukai dan sering diterapkan oleh seorang pemimpin. Gaya kepemimpinan menunjukkan secara langsung maupun tidak langsung, tentang keyakinan seorang pimpinan terhadap kemampuan bawahannya. Artinya gaya kepemimpinan adalah perilaku dan strategi, sebagai hasil kombinasi dari falsafah, keterampilan, sifat, sikap, yang sering diterapkan seorang pemimpin ketika ia mencoba memengaruhi kinerja bawahannya.

Sementara itu, motivasi kerja adalah penggerak atau pendorong dalam diri seseorang untuk mau berperilaku dan bekerja dengan giat dan baik sesuai dengan tugas dan kewajiban yang telah diberikan kepadanya (Kadarisma, 2012:278). Motivasi berasal dari kata dasar motif yang mempunyai arti suatu perangsang, keinginan, dan daya penggerak kemauan kerja seseorang. Motivasi Kerja merupakan motivasi yang terjadi pada situasi dan lingkungan kerja yang terdapat pada suatu organisasi atau instansi. Elemen yang terkandung dalam motivasi meliputi unsur membangkitkan, mengarahkan, menjaga, menunjukkan intesitas, bersifat terus-menerus dan adanya tujuan (Robbins \& Coulter, 2012).

Sedangkan lingkungan kerja adalah segala sesuatu yang ada di sekitar para pekerja, dan yang dapat memengaruhi dirinya dalam menjalankan tugas-tugas yang dibebankan, misalnya kebersihan, musik, penerangan dan lain-lain (Sunyoto, 2012:43). Tidak jauh berbeda dengan pendapat Nitisemito dalam Nuraini (2013:97), bahwa lingkungan kerja adalah segala sesuatu yang ada disekitar karyawan, dan dapat mempengaruhi dalam menjalankan tugas yang diembankan kepadanya, misalnya dengan adanya air conditioner (AC), penerangan yang memadai, dan sebagainya. Lingkungan kerja dapat memengaruhi para pekerja dalam menjalankan tugas, seperti temperatur, kelembapan, ventilasi, penerangan, kegaduhan, kebersihan tempat kerja, dan memadai tidaknya alat-alat perlengkapan kerja.

Berdasarkan latar belakang tersebut, dapat disusun beberapa hipotesis yang dapat mempengaruhi kinerja karyawan, diantaranya yakni:

1. Ha1: Terdapat pengaruh gaya kepemimpinan terhadap kinerja karyawan PT. Asuransi Jiwasraya (Persero) di Bandar Lampung.

2. Ha2: Terdapat pengaruh motivasi kerja terhadap kinerja karyawan PT. Asuransi Jiwasraya (Persero) di Bandar Lampung.

3. Ha3: Terdapat pengaruh lingkungan kerja terhadap kinerja karyawan PT. Asuransi Jiwasraya (Persero) di Bandar Lampung.

4. Ha4: Terdapat pengaruh gaya kepemimpinan, motivasi kerja, dan lingkungan kerja secara simultan terhadap kinerja karyawan PT. Asuransi Jiwasraya (Persero) di Bandar Lampung.

\section{METODE PENELITIAN}


Penelitian ini merupakan penelitian kuantitatif, menggunakan kuesioner yang disebarkan kepada 74 orang responden yang menjadi sampel dalam penelitian ini. Penelitian dilakukan di PT. Asuransi Jiwasraya (Persero) Bandar Lampung yang terletak di Jl. Raden Intan No.67, Kota Bandar Lampung, Provinsi Lampung.

Data dianalisis dengan beberapa tahapan, tahap pertama melakukan uji instrumen, dengan menggunakan uji validitas dan reliabilitas, untuk mengetahui butir-butir pernyataan pada kuesioner layak digunakan sebagai bahan penelitian atau tidak. Tahap kedua yaitu menguji asumsi klasik untuk menentukan kelayakan model pada regresi. Uji asumsi klasik penelitian ini yaitu dengan menggunakan uji kolomogrov smirnov, uji multikolonieritas, uji heteroskedasitas, dan uji autokorelasi Durbin-watson. Tahap ketiga yaitu menguji hipotesis menggunakan regresi linier berganda melalui uji T-test dan uji Ftest, dan koefisien determinasi $\left(\mathrm{R}^{2}\right)$.

Variabel gaya kepemimpinan diukur dengan menggunakan beberapa indikator, seperti kemampuan mengambil keputusan, kemampuan memotivasi, kemampuan komunikasi, tanggung jawab, dan kemampuan mengendalikan emosi. Sementara itu, indikator pada variabel motivasi kerja meliputi dorongan dalam mencapai tujuan, semangat kerja, inisiatif dan kreatifitas, dan rasa tanggung jawab.

Pada variabel lingkungan kerja, indikator yang digunakan dalam pengukuran adalah cahaya-cahaya penerangan yang cukup, dekorasi tempat kerja, warna, udara, suara. Sedangkan pada variabel kinerja karyawan, indikator yang digunakan meliputi pemahaman atas tugas pokok dan fungsi, inovasi, kecepatan kerja, keakuratan kerja, dan kerja sama.

\section{HASIL PENELITIAN}

\section{Karakteristik Responden}

Responden dalam penelitian ini, sebanyak 40 orang $(54.1 \%)$ berjenis kelamin lakilaki, dan sisanya 34 orang $(45,9 \%)$ adalah perempuan.

\section{Hasil Uji Instrumen}

Berdasarkan hasil uji instrumen terhadap 74 responden, dapat disimpulkan bahwa rhitung > r tabel $(0,374)$, dan nilai cronbach's alpha lebih dari 0,60, sehingga seluruh item pertanyaan dinyatakan valid dan reliabel (Lihat tabel 1 dan 2).

Tabel 1. Hasil Uji Validitas

\begin{tabular}{|l|c|c|c|c|}
\hline \multirow{4}{*}{ Variabel } & Pernyataan & $\mathbf{r}_{\text {hitung }}$ & $\mathbf{r}_{\text {tabel }}$ & Keterangan \\
\hline \multirow{4}{*}{$\begin{array}{l}\text { Gaya Kepemimpinan } \\
(X 1)\end{array}$} & Item 1 & 0,661 & 0,374 & Valid \\
\cline { 2 - 5 } & Item 2 & 0,689 & 0,374 & Valid \\
\cline { 2 - 5 } & Item 3 & 0,875 & 0,374 & Valid \\
\cline { 2 - 5 } & Item 4 & 0,395 & 0,374 & Valid \\
\cline { 2 - 5 } & Item 5 & 0,810 & 0,374 & Valid \\
\hline \multirow{3}{*}{ Motivasi Kerja (X2) } & Item 1 & 0,625 & 0,374 & Valid \\
\cline { 2 - 5 } & Item 2 & 0,864 & 0,374 & Valid \\
\cline { 2 - 5 } & Item 3 & 0,871 & 0,374 & Valid \\
\hline
\end{tabular}




\begin{tabular}{|l|c|c|c|c|}
\hline & Item 4 & 0,698 & 0,374 & Valid \\
\hline \multirow{4}{*}{ Lingkungan Kerja (X3) } & Item 1 & 0,699 & 0,374 & Valid \\
\cline { 2 - 5 } & Item 2 & 0,871 & 0,374 & Valid \\
\cline { 2 - 5 } & Item 3 & 0,801 & 0,374 & Valid \\
\cline { 2 - 5 } & Item 4 & 0,731 & 0,374 & Valid \\
\hline \multirow{3}{*}{ Kinerja Karyawan (Y) } & Item 1 & 0,660 & 0,374 & Valid \\
\cline { 2 - 5 } & Item 2 & 0,828 & 0,374 & Valid \\
\cline { 2 - 5 } & Item 3 & 0,685 & 0,374 & Valid \\
\cline { 2 - 5 } & Item 4 & 0,600 & 0,374 & Valid \\
\cline { 2 - 5 } & Item 5 & 0,851 & 0,374 & Valid \\
\hline
\end{tabular}

Sumber: Data Diolah, 2019

Tabel 2 Hasil Uji Reliabilitas

\begin{tabular}{|l|c|c|}
\hline \multicolumn{1}{|c|}{ Variabel } & $\begin{array}{c}\text { Nilai Cronbach's } \\
\text { Alpha }\end{array}$ & $\begin{array}{c}\text { Reliabilita } \\
\text { s }\end{array}$ \\
\hline $\begin{array}{l}\text { Gaya Kepemimpinan } \\
\mathrm{X}_{1}\end{array}$ & 0,741 & Reliabel \\
\hline Motivasi Kerja $\mathrm{X}_{2}$ & 0,762 & Reliabel \\
\hline Lingkungan Kerja $\mathrm{X}_{3}$ & 0,763 & Reliabel \\
\hline Kinerja Karyawan Y & 0,766 & Reliabel \\
\hline
\end{tabular}

Sumber: Data Diolah, 2019

Analisis Regresi Linier Berganda

Berikut adalah hasil dari analisis regresi linier berganda berdasarkan perhitungan dengan menggunakan program SPSS 20.

Tabel 3. Hasil Analisis Regresi Linier Berganda

Coefficients ${ }^{2}$

\begin{tabular}{|c|c|c|c|c|c|c|c|c|}
\hline \multirow{2}{*}{\multicolumn{2}{|c|}{ Model }} & \multicolumn{2}{|c|}{ Unstandardized Coefficients } & \multirow{2}{*}{$\begin{array}{c}\begin{array}{c}\text { Standardized } \\
\text { Coefficients }\end{array} \\
\text { Beta }\end{array}$} & \multirow[b]{2}{*}{$t$} & \multirow[b]{2}{*}{ Sig. } & \multicolumn{2}{|c|}{ Collinearity Statistics } \\
\hline & & B & Std. Error & & & & Tolerance & VF \\
\hline \multirow[t]{4}{*}{1} & (Constant) & 12,679 & 2,282 & & 5,556 & .000 & & \\
\hline & Gaya_Kepemimpinan & 083 & .036 & 257 & 2,316 & .023 & .859 & 1,164 \\
\hline & Motrvasi_Keria & .338 &, 083 & .434 & 4,072 & .000 & 932 & 1,073 \\
\hline & Lingkungan_kerja & .197 &, 098 & 218 & 2,022 & .047 & 909 & 1,100 \\
\hline
\end{tabular}

a. Dependent Variable. Kineria_Pegawa

Sumber: Data Diolah, 2019

Berdasarkan tabel 3, diperoleh persamaan regresi:

$$
Y=12,679+0,083 X_{1}+0,338 X_{2}+0,197 X_{3}+0,05
$$

Adapun penjelasannya dapat diuraikan sebagai berikut:

1. Persamaan regresi dalam penelitian ini memiliki konstanta sebesar 12,679 yang berarti bahwa jika variabel independen gaya kepemimpinan (X1), motivasi kerja (X2), lingkungan kerja $(X 3)$ memiliki nilai 0 , maka nilai variabel dependen kinerja karyawan (Y) adalah sebesar 12,679. 
2. Koefisien regresi $X_{1}=0,083$ menyatakan bahwa setiap penambahan satu satuan $X_{1}$ (Gaya Kepemimpinan) maka akan meningkatkan kinerja karyawan sebesar 0,083 satuan.

3. Koefisien regresi $X_{2}=0,338$ menyatakan bahwa setiap penambahan satu satuan $X_{2}$ (Motivasi Kerja) maka akan meningkatkan kinerja karyawan sebesar 0,338 satuan.

4. Koefisien regresi $X_{3}=0,197$ menyatakan bahwa setiap penambahan satu satuan $X_{3}$ (Lingkungan Kerja) maka akan meningkatkan kinerja karyawan sebesar 0,197 satuan.

Uji Hipotesis

Uji $t$

Coefficients $^{\mathrm{a}}$

Tabel 4 Hasil Uji t

\begin{tabular}{|c|c|c|c|c|c|}
\hline \multirow[t]{2}{*}{ Model } & \multicolumn{2}{|c|}{$\begin{array}{l}\text { Unstandardized } \\
\text { Coefficients }\end{array}$} & \multirow{2}{*}{\begin{tabular}{|c|}
$\begin{array}{c}\text { Standardized } \\
\text { Coefficients }\end{array}$ \\
Beta \\
\end{tabular}} & \multirow[t]{2}{*}{$\mathrm{T}$} & \multirow[t]{2}{*}{ Sig. } \\
\hline & B & Std. Error & & & \\
\hline (Constant) & 12,679 & 2,282 & & 5,556 & ,000 \\
\hline $\begin{array}{l}\text { Gaya_Kepemimpin } \\
\text { an }\end{array}$ & 083 & 036 & 257 & 2,316 & 023 \\
\hline Motivasi_Kerja & ,338 & 083 & 434 & 4,072 & ,000 \\
\hline Lingkungan_kerja & 197 & ,098 & 218 & 2,022 & ,047 \\
\hline
\end{tabular}

a. Dependent Variable: Kinerja_Karyawan

Sumber: Data Diolah, 2019

1. Berdasarkan hasil perhitungan pada tabel coefficients di atas, diperoleh nilai tHitung $(2,316)>t_{\text {tabel }}(1,994)$, dengan nilai signifikansi $0,023<0,05$, artinya artinya Ha diterima, Ho ditotak. Maka, dapat disimpulkan bahwa variabel gaya kepemimpinan (X1) secara parsial berpengaruh terhadap kinerja karyawan (Y) PT. Asuransi Jiwasraya (Persero) di Bandar Lampung.

2. Berdasarkan hasil perhitungan pada tabel coefficients di atas diperoleh nilai $t_{\text {Hitung }}$ $(4,072)>$ tabel $(1,994)$, dengan nilai signifikansi $0,000<0,05$, artinya Ha diterima, Ho ditotak. Maka, dapat disimpulkan bahwa variabel motivasi kerja (X2) secara parsial berpengaruh terhadap kinerja karyawan (Y) PT. Asuransi Jiwasraya (Persero) di Bandar Lampung.

3. Berdasarkan hasil perhitungan pada tabel coefficients di atas diperoleh nilai $t_{\text {Hitung }}$ $(2,022)>t_{\text {tabel }}(1,994)$, dengan nilai signifikansi $0,047<0,05$, artinya Ha diterima, Ho ditotak. Maka, dapat disimpulkan bahwa variabel lingkungan kerja (X3) secara parsial berpengaruh terhadap kinerja karyawan (Y) PT. Asuransi Jiwasraya (Persero) di Bandar Lampung.

Uji F

Berdasarkan hasil uji F pada tabel 5, dapat dilihat bahwa F hitung $(8,103)>\mathrm{F}$ tabel $(3,13)$, dan nilai signifikansi $0,00<a(0,05)$. Maka, dapat disimpulkan bahwa gaya 
kepemimpinan, motivasi kerja dan lingkungan kerja secara simultan berpengaruh terhadap kinerja karyawan PT. Asuransi Jiwasraya (Persero) di Bandar Lampung.

Tabel 5. Hasil Uji F

ANOVA $^{a}$

\begin{tabular}{|c|c|c|c|c|c|c|}
\hline & Model & Sum of Squares & Df & Mean Square & $\mathbf{F}$ & Sig. \\
\hline 1 & $\begin{array}{l}\text { Regression } \\
\text { Residual } \\
\text { Total }\end{array}$ & $\begin{array}{l}14,564 \\
41,936 \\
56,500\end{array}$ & $\begin{array}{c}3 \\
70 \\
73\end{array}$ & $\begin{array}{c}4,855 \\
, 599\end{array}$ & 8,103 &, $000^{\mathrm{b}}$ \\
\hline
\end{tabular}

a. Dependent Variable: Kinerja_Karyawan

b. Predictors: (Constant), Lingkungan kerja, Motivasi_Kerja, Gaya_Kepemimpinan

Sumber: Data Diolah, 2019

Koefisien Determinasi $\left(R^{2}\right)$

Tabel 6. Hasil Koefisien Determinasi $\left(\mathrm{R}^{2}\right)$

Model Summary b

\begin{tabular}{|l|r|r|r|r|}
\hline Model & R & R Square & Adjusted R Square & Std. Error of the Estimate \\
\hline 1 &, $508^{\mathrm{a}}$ &, 258 &, 226 &, 774 \\
\hline
\end{tabular}

a. Predictors: (Constant), Lingkungan_kerja, Motivasi_Kerja, Gaya_Kepemimpinan

b. Dependent Variable: Kinerja_Karyawan

Sumber: Data Diolah, 2019

Berdasarkan hasil koefisien determinasi, dimana untuk regresi dengan lebih dari dua variabel bebas digunakan adjusted $R$ square besarnya adalah 0,226 . Hal ini menunjukkan bahwa kinerja karyawan dipengaruhi oleh gaya kepemimpinan, motivasi kerja dan lingkungan kerja sebesar22,6\%, sedangkan sisanya sebesar 77,4\% dipengaruhi oleh faktor lain yang tidak termasuk ke dalam penelitian ini.

\section{PEMBAHASAN}

$H_{1}$ : Pengaruh variabel gaya kepemimpinan terhadap kinerja karyawan

Hasil dari penelitian ini menunjukan bahwa hasil hipotesis uji-t diperoleh nilai $t_{H i t u n g}$ sebesar 2,316 $>t_{\text {tabel }} 1,994$ atau nilai signifikansi sebesar 0,023 $<$ alpha 0,05. Maka, dapat disimpulkan bahwa variabel Gaya Kepemimpinan $\left(X_{1}\right)$ secara parsial berpengaruh terhadap Kinerja Karyawan (Y) pada PT. Asuransi Jiwasraya (Persero) di Bandar Lampung. Hasil penelitian ini juga diperkuat dengan hasil penelitian terdahulu yang dilakukan oleh Hidayat, et al. (2018) yang menyatakan bahwa gaya Kepemimpinan berpengaruh positif signifikan terhadap kinerja karyawan.

$\mathrm{H}_{2}$ : Pengaruh variabel motivasi kerja terhadap kinerja karyawan

Hasil dari penelitian ini menunjukan bahwa hasil hipotesis uji-t diperoleh nilai $t_{\text {Hitung }}$ 
sebesar 4,072 $>t_{\text {tabel }} 1,994$ atau nilai signifikansi sebesar 0,000 $<$ alpha 0,05. Maka, dapat disimpulkan bahwa variabel motivasi kerja $\left(X_{2}\right)$ secara parsial berpengaruh terhadap kinerja karyawan (Y) pada PT. Asuransi Jiwasraya (Persero) di Bandar Lampung. Hasil penelitian ini juga diperkuat dengan hasil penelitian terdahulu yang dilakukan oleh Wibowo, et al. (2017) yang menyatakan bahwa motivasi kerja berpengaruh positif signifikan terhadap kinerja karyawan.

\section{$H_{3}$ : Pengaruh variabel lingkungan kerja terhadap kinerja karyawan}

Hasil dari penelitian ini menunjukan bahwa hasil hipotesis uji-t diperoleh nilai $\mathrm{t}_{\text {Hitung }}$ sebesar 2,022 $>\mathrm{t}_{\text {tabel }}$ 1,994 atau nilai signifikansi sebesar 0,047 < alpha 0,05. Maka, dapat disimpulkan bahwa variabel lingkungan kerja $\left(\mathrm{X}_{3}\right)$ secara parsial berpengaruh terhadap kinerja karyawan (Y) pada PT. Asuransi Jiwasraya (Persero) di Bandar Lampung. Hasil penelitian ini juga diperkuat dengan hasil penelitian terdahulu yang dilakukan oleh Yuniarsih, et al. (2017) yang menyatakan bahwa lingkungan kerja berpengaruh positif signifikan terhadap kinerja karyawan.

\section{$H_{4}$ : Pengaruh varibel gaya kepemimpinan, motivasi kerja dan lingkungan kerja terhadap kinerja karyawan}

Hasil dari penelitian ini menunjukan bahwa hasil hipotesis pengujian Uji-F didapatkan

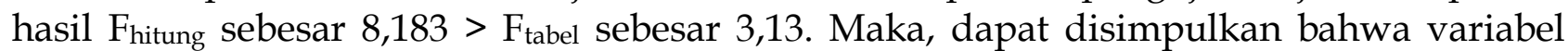
gaya kepemimpinan $\left(X_{1}\right)$, motivasi kerja $\left(X_{2}\right)$ dan lingkungan kerja $\left(X_{3}\right)$ berpengaruh secara simultan terhadap kinerja karyawan (Y) pada PT. Asuransi Jiwasraya (Persero) di Bandar Lampung. Pengaruh terbesar terletak pada variabel motivasi kerja sebesar 0,434, diikuti dengan gaya kepemimpinan $(0,257)$, dan lingkungan kerja $(0,218)$.

\section{KESIMPULAN}

Berdasarkan hasil analisis, dapat disimpulkan bahwa terdapat pengaruh yang positif dan signifikan secara parsial maupun simultan gaya kepemimpinan $\left(\mathrm{X}_{1}\right)$, motivasi kerja $\left(X_{2}\right)$ dan lingkungan kerja $\left(X_{3}\right)$ terhadap kinerja karyawan $(Y)$ pada PT. Asuransi Jiwasraya (Persero) di Bandar Lampung. Pengaruh terbesar terletak pada variabel motivasi kerja, yang meliputi dorongan dalam mencapai tujuan, semangat kerja, inisiatif dan kreatifitas, dan rasa tanggung jawab. Perlu adanya peningkatan terhadap fasilitas kerja dan gaya kepemimpinan yang dapat memotivasi karyawan sebagai variabel dengan nilai pengaruh yang lebih rendah.

\section{DAFTAR PUSTAKA}

Hidayat, A., Sudirja, \& Kohar, N. (2018). “Analisa pengaruh gaya kepemimpinan terhadap kinerja karyawan pada suku dinas kebersihan Kota Administrasi Jakarta Timur". Jurnal STIE Kusumanegara. Diakses dari http://journal.stie-kusumanegara.ac.id/index.php/managerial/article/view/18.

Kadarisman, M. (2012). Manajemen pengembangan sumber daya manusia. Edisi Pertama. Jakarta: Rajawali Press. Nuraini, T. (2013). Manajemen sumber daya manusia. Pekanbaru: Yayasan Aini Syam. 
Sunyoto, D. (2012). Manajemen sumber daya manusia. Yogyakarta: CAPS.

Thoha, M. (2014). Manajemen kekaryawanan sipil di Indonesia. Jakarta: Prenadamedia Group.

Wibowo, F. R., Djudi, M., \& dan Ruhana, I. (2017). "Pengaruh motivasi kerja dan kemampuan kerja terhadap kinerja karyawan (Studi pada PT. PLN (Persero) distribusi Jawa Timur area Surabaya)”. Jurnal Administrasi Bisnis. Diakses dari http://administrasibisnis.studentjournal.ub.ac.id/index.php/jab/article/view/1673.

Yuniarsih, S., Hasiholan, L. B., \& Yulianeu. (2017). “Pengaruh kepemimpinan, motivasi, dan lingkungan kerja terhadap kinerja karyawan pada perum Damri kantor divisi regional II Semarang". Jurnal Unpand. Diakses dari http://jurnal.unpand.ac.id/index.php/MS/article/view/856.

Zainal, V. R., Hadad, M. D., \& Ramly, M. R. (2014). Kepemimpinan dan perilaku organisasi. Jakarta: Raja Grafindo Persada. 